\title{
Taphonomy and Sedimentological Significance of Oyster Shell Beds within Cretaceous Transgressive Sediments in Japan
}

\author{
Hisao Ando \\ Department of Earth Science, Faculty of Science, Ibaraki University, Mito, Japan \\ Email: Hisao.ando.sci@vc.ibaraki.ac.jp
}

How to cite this paper: Ando, H. (2019) Taphonomy and Sedimentological Significance of Oyster Shell Beds within Cretaceous Transgressive Sediments in Japan. Open Journal of Geology, 9, 547-550. https://doi.org/10.4236/ojg.2019.910038

Received: August 15, 2019

Accepted: September 17, 2019

Published: September 20, 2019

Copyright (อ 2019 by author(s) and Scientific Research Publishing Inc. This work is licensed under the Creative Commons Attribution International License (CC BY 4.0).

http://creativecommons.org/licenses/by/4.0/

\section{(c) (i) Open Access}

\begin{abstract}
Through taphonomical analyses of Crassostrea shell beds included in several Japanese Cretaceous strata, paleoecological and sedimentological significance of intertidal muddy and sandy bottom dwelling oysters are examined. The Upper Cretaceous Crassostrea shell beds show a variety of modes of occurrence, lithological changes and sedimentary structure, suggesting composite formative, paleoecological and sedimentary processes. Crassostrea seems to have adapted from muddy substratum during early Cretaceous to coarser sandier substratum often influenced by physical turbulence such as tidal currents and waves during the mid-Cretaceous time, associated with increasing in shell size and thickness, and colony dimension.
\end{abstract}

\section{Keywords}

Taphonomy, Oyster, Crassostrea, Cretaceous, Japan

\section{Introduction}

Oysters are sessile and suspension filter-feeding bivalves living on rocky/shelly ground as epifauna and sand/mud bottom as epi-/semi-infauna [1]. Among several genera of oysters, Crassostrea has adapted to muddy tidal flat in brackish-water inner bay areas since Late Jurassic, often forming large-scale colonies/reefs [2]. Because Crassostrea shell beds are often recognized in Japanese Cretaceous strata, they provide useful information on sedimentary processes of the estuary deposits as well as paleoecology of Crassostrea and its reefs.

\section{Paleoecological and Sedimentological Significance}

Physically unstable, brackish and tide-influenced muddy tidal flat is not suitable 
for filter feeding benthos because of high sedimentation rate and soupy substrate easily subject to burial and smothering of gill by suspended mud. However, Crassostrea could overcome these problems by the lightweight shell microstructure and a relay-type ecological strategy that new generations of individuals grow upward attached to other shells of the previous generations as a response to the rising sediment surface and succeeded in occupying a large niche. As it has flourished since early Cretaceous, many large-scale Crassostrea shell beds are found in several strata of various ages and areas, also in Japan.

Sedimentologically, Crassostrea shell beds are a good index for inner bay brackish environments as a facies fossil. In general, estuary and inner bay systems tend to be formed during transgressive stages. Their sediments and Crassostrea shell beds are mostly restricted to incised valley fills within transgressive systems tracts (TST). Crassostrea shell beds are one of keys for evaluating formation processes of TST.

Because of active bioturbation in estuary and inner bay environments, strata are usually massive and lack of physical sedimentary structures. But autochthonous oyster shell beds preserve the original features of colonies/reefs such as growth patterns of individuals and colonies as well as burial processes. Semi-autochthonous and even allochthonous shell beds also record event stratifications and accumulations such as storm/tidal/tsunami erosion and reworking.

Crassostrea shells and their fragments are often reworked and transported into shallow open-marine environments by waves and tidal and storm currents. Crassostrea reefs may have been eroded through shoreface erosion during transgression and provide a large amount of reworked shells into shoreface. Crassostrea reefs are one of large carbonate factories/sources providing shell materials in siliciclastic shallow shelf setting in the Northwest Pacific region.

\section{Crassostrea Shell Bed Distribution in Cretaceous Strata of Japan}

Japanese Cretaceous strata are distributed reflecting the tectonic setting of Cretaceous arc-trench system composed of backarc, intra-arc, forearc and trench-fill basins [3]. In the intra-arc side Crassostrea shell beds are found in the Lower Cretaceous strata such as the Yoshino Formation (Fm) (Berriasian-Valanginian), Toyonishi Group (Gr) in west Honshu, and the Ushimaru Fm (Hauterivian-Barremian), Tetori Gr in central Honshu, represented by Crassostrea ryosekhiensis and C. tetoriensis, respectively.

On the other hand, along the forearc side from SW to NE, 1) Goshoura (Albian-Cenomanian) and Mifune Grs (Cenomanian) represented by $C$. kawauchidensis, 2) Himenoura Gr (Campanian) in Kyushu, 3) Shiroyama Fm (Upper Campanian), Izumi Gr in Shikoku, 4) Tamagawa Fm (Upper Turonian-Lower Coniacian), Kuji Gr in north Honshu, 5) Mikasa Fm (Upper Cenomanian-Lower Turonian), Yezo Gr and 6) Hakobuchi Fm (Upper Campanian), Yezo Gr in Hokkaido, include characteristic shell beds in mode of fossil occurrence respectively. Except 1) for C. kawauchidensis, Crassostrea species in 2) to 
6) are still not taxonomically identified. However, their stratigraphic ranges generally cover the whole Cretaceous: Lower Cretaceous by the intra-arc strata, and mid and Upper Cretaceous by the forearc strata.

\section{Paleoecological Trends on Crassostrea and Shell Beds}

Early Cretaceous Crassostrea species tend to be smaller less than $15 \mathrm{~cm}$ in size (shell height) and thinner in shell thickness, though they form bouquet-like small patchy shell concentrations. They generally occur from muddy lithofacies suggesting sporadic small patchy reefs on muddy tidal flat substratum.

Mid- and Late Cretaceous species are generally thicker than a few $\mathrm{cm}$ and longer than several tens $\mathrm{cm}$ at maximum, and form thick shell beds over several tens' $\mathrm{cm}$ long, occasionally over $1 \mathrm{~m}$. They often constitute composite/multiple-event shell beds formed by intermittent colonization and physical reworking units within each bed. Several shell beds are intercalated with fine sandy layers without fossil shells in a thick intertidal sandstone section as exemplified in the Tamagawa Fm, Kuji Gr. The mid- and Upper Cretaceous shell beds tend to be silty very fine to fine sandstone in lithology, and coarser than the Lower Cretaceous ones.

This suggests that Crassostrea adapted from muddy substratum to coarser sandier substratum influenced by tidal currents and waves with increasing in shell size and thickness, and colony dimension during the mid-Cretaceous time.

\section{Conclusion}

Crassostrea shell beds often included in the Cretaceous transgressive deposits in intra-arc and forearc basins in Japan, provide important information on their taphonomical and sedimentological formative processes. Crassostrea and its related species have adapted from muddy tidal flat in brackish-water inner bay areas during early Cretaceous also to sandier tidal flat often influenced by tidal currents and waves during the mid-Cretaceous time, with general trends of increasing in shell size and thickness, and colony dimension.

\section{Acknowledgements}

This study was supported financially by Grant-in-Aid for Scientific Research (C) (No.17K05688). This is a contribution to UNESCO-IUGS IGCP Project 679.

\section{Conflicts of Interest}

The author declares no conflicts of interest regarding the publication of this paper.

\section{References}

[1] Stenzel, H.B. (1971) Oysters. In: Cox, L.R., et al., Eds., Treatise on Invertebrate Paleontology. Mollusca 6, Part N, 3 of 3, 953-1224.

[2] Chinzei, K. (2013) Adaptation of Oysters to Life on Soft Substrates. Historical Biol- 
ogy, 25, 223-231. https://doi.org/10.1080/08912963.2012.727412

[3] Ando, H. and Takahashi, M. (2017) Reconstruction of the Cretaceous Paleo-Japan Continental Arc-Trench System Reconsidered from Cretaceous Geologic Records in the Japanese Islands. Kaseki (Fossil), 102, 43-62. 